\title{
Judgments and decisions
}

\section{JUDGMENTS OF INTERNATIONAL AND NATIONAL COURTS}

\section{International}

\section{Arbitral Tribunal}

Alabama claims of the United States of America against Great Britain, Award issued on 14 September 1872, T Bingham, The Alabama Claims Arbitration, 50(1) ICQL (2005)

BP Exploration Co. (Libya) Ltd. v. Government of the Libyan Arab Republic, 1973/1974, 53 I.L.R. 297, 375

Kuwait v. Aminoil, 1982, 21 I.L.M. 976

Lac Lanoux Arbitration (Spain v. France), Judgment of 16 November 1957, R.I.A.A. 281;

24 I.L.R. 101 p. 182 n56

Libyan American Oil Company v. Libyan Arab Republic, 1977, 62 I.L.R. 140

203, 211

Mohamed Abdulmohsen Al-Kharafi \& Sons Co. v. Libya, Final Award issued on 22 March

2013, Cairo Regional Centre for International Commercial Arbitration

Petroleum Development (Trucial Coast) Ltd. v. Sheikh of Abu Dhabi, 1951,

18 I.L.R. 144

Ruler of Qatar v. Int'l Marine Oil Co., 1953, 20 I.L.R. 534 ................................................... 203

Sapphire International Petroleums Ltd. v. National Iranian Oil Company, 1963, 35 I.L.R. 136

Saudi Arabia v. Arabian Am. Oil Co., 1958, 27 I.L.R. 117

Texaco Overseas Petroleum Company and California Asiatic Oil Company v. Government of Libya, 1979, 53 I.L.R. 389

The Delgoa Railway Arbitration Case (Great Britain and United States v. Portugal), 1900, JI Moreira, The Delagoa Railway Arbitration Case: The Geo-politics of Investment Arbitration in the Late 19th Century, 13(3) TDM (2016)

The Lena Goldfields Arbitration, 1930, A Nussbaum, The Arbitration between the Lena Goldfields, Ltd. and the Soviet Government, 36 Cornell Law Quarterly (1950), p. 31

\section{European Court of Human Rights}

Al-Jedda v. The United Kingdom (application no. 27021/08), Judgment of 7 July 2011

\section{European Union}

Council Directive (EC) on 'the implementation of the principle of equal opportunities and equal treatment of men and women in matters of employment and occupation' (recast), 2006/54/EC (5 July 2006), L 204/23

Council Directive (EC) on "minimum standards for the qualification and status of third country nationals or stateless persons as refugees or as persons who otherwise need international protection and the content of the protection granted', 2004/83/EC (29 April 2004) ...... 310

Council Directive (EC) on 'implementing the principle of equal treatment between men and women in the access to and supply of goods and services', 2004/113/EC (13 December 2004), L 373/37 
Council Directive (EC) on implementing the principle of equal treatment between persons irrespective of racial or ethnic origin', 2000/43/EC (29 June 2000), L 180

Council Directive (EC) on 'establishing a general framework for equal treatment in employment and occupation', 2000/78/EC (27 November 2000), L 303

\section{General Agreement on Tariffs and Trade Dispute Settlement}

Differential and More Favourable Treatment Reciprocity and Fuller Participation of Developing Countries, Decision of 28 November 1979, GATT Doc. L/4903

(3 December 1979)

General Agreement on Tariffs and Trade Council on 29 May 1985, GATT Doc. C/M/188 (28 June 1985)

United States - Trade Measures Affecting Nicaragua, Communication from Nicaragua of 6 May 1985, GATT Doc. L/5802 (8 May 1985)

United States - Trade Measures Affecting Nicaragua, panel report of 13 October 1986 (unadopted), GATT Doc. L/6053 (13 October 1986)

\section{Inter-American Court of Human Rights}

Velásquez-Rodríguez v. Honduras, Judgment of 29 July 1988. Inter-American Court of Human Rights, see http://www.corteidh.or.cr/docs/casos/articulos/seriec_04_ing.pdf (accessed 12 November 2014)

\section{International Centre for Settlement of Investment Disputes}

Al Jazeera Media Network v. Arab Republic of Egypt, 2016, pending, ICSID Case No.

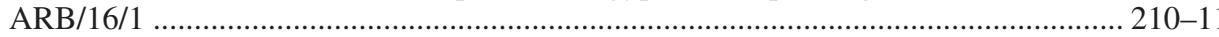

American Manufacturing \& Trading, Inc. v. Republic of Zaire, Award issued on 21 February 1997, ICSID Case No. ARB/93/1

Ampal-American Israel Corp. \& Others v. Arab Republic of Egypt, Decision on Liability,

21 February 2017, ICSID Case No. ARB/12/11 208, 210-11

ArcelorMittal S.A. v. Arab Republic of Egypt, 2016, settled, ICSID Case No. ARB/15/47

ASA International S.p.A. v. Arab Republic of Egypt, 2016, discontinued, ICSID Case No. $\mathrm{ARB} / 13 / 37$

Asian Agricultural Products Ltd v. Republic of Sri Lanka, Final Award issued on 27 June 1990, ICSID Case No. ARB/87/3

Cementos La Union S.A. \& Aridos Jativa S.L.U v. Arab Republic of Egypt, 2013, pending, ICSID Case No. ARB/13/29

Champion Holding Co. and Others v. Arab Republic of Egypt, 2016, pending, ICSID Case No. ARB/16/2

Future Pipe International B.V. v. Arab Republic of Egypt, 2017, pending, ICSID Case No.

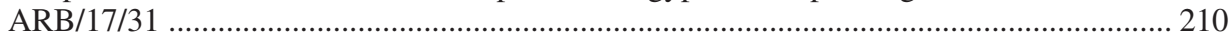

Itisaluna Iraq LLC \& Others v. Republic of Iraq, 2017, pending, ICSID Case No. $\mathrm{ARB} / 17 / 10$

LP Egypt Holdings I, LLC, Fund III Egypt, LLC and OMLP Egypt Holdings I, LLC v. Arab Republic of Egypt, 2016, pending, ICSID Case No. ARB/16/37

Ossama Al Sharif I v. Arab Republic of Egypt, 2015, settled, ICSID Case No. $\mathrm{ARB} / 13 / 3$

Ossama Al Sharif II v. Arab Republic of Egypt, 2015, settled, ICSID Case No. $\mathrm{ARB} / 13 / 4$

Ossama Al Sharif III v. Arab Republic of Egypt, 2015, settled, ICSID Case No. $\mathrm{ARB} / 13 / 3$

Pantechniki SA Contractors \& Engineers v. The Republic of Albania, Award issued on 30 July 2009, ICSID Case No. ARB/07/21 
Salini Costruttori S.p.A. \& Italstrade S.p.A. v. Kingdom of Morocco, Decision on Jurisdiction of 21 July 2001, ICSID Case No. ARB/00/4

Straberg SE v. Libya, 2015, pending, ICSID Case No. ARB(AF)15/1

Unión Fenosa Gas, S.A. v. Arab Republic of Egypt, 2014, pending, ICSID Case No.

$\mathrm{ARB} / 14 / 4$

Utsch M.O.V.E.R.S. International GmbH, Erich Utsch Aktiengesellschaft, \& Helmut

Jungbluth v. Arab Republic of Egypt, 2017, discontinued, ICSID Case No.

ARB/13/37

Veolia Propreté v. Arab Republic of Egypt, Award issued on 30 May 2018, ICSID Case

No. ARB/12/15

$210-11$

\section{International Court of Justice}

Accordance with International Law of the Unilateral Declaration of Independence in Respect of Kosovo, Advisory Opinion of 22 July 2010, ICJ Reports 2010

Application of Interim Accord of 13 September 1995 (the former Yugoslav Republic of

Macedonia v. Greece), Judgment of 5 December 2011, ICJ Reports 2011 88

Application of the Convention on the Prevention and Punishment of the Crime of Genocide

(Bosnia and Herzegovina v. Serbia and Montenegro), Judgment of 26 February 2007,

ICJ Reports 2007 $429,442,448$

Application of the Convention on the Prevention and Punishment of the Crime of Genocide

(Bosnia and Herzegovina v. Serbia and Montenegro), Provisional Measures,

8 April 1993, ICJ Reports 1993

Application of the International Convention for the Suppression of the Financing of Terrorism

and of the International Convention on the Elimination of All Forms of Racial

Discrimination (Ukraine v. Russian Federation), Provisional Measures, 19 April 2017,

General List No. 166

Application of the International Convention on the Elimination of All Forms of Racial

Discrimination (Georgia v. Russian Federation), Judgment of 1 April 2011,

ICJ Reports 2011

Application of the International Convention on the Elimination of All Forms of Racial

Discrimination (Georgia v. Russian Federation), Preliminary Objections,

1 April 2011, ICJ Reports 2011

Application of the International Convention on the Elimination of all Forms of Racial

Discrimination (Georgia v. Russian Federation), Provisional Measures, 12 August 2008,

General List No. 140 287,433

Application of the International Convention on the Elimination of All Forms of Racial

Discrimination (Qatar v. United Arab Emirates), Request for the indication of provisional

measures, 11 June 2018

Armed Activities on the Territory of the Congo (Democratic Republic of the Congo v.

Uganda), Judgment of 19 December 2005, ICJ Reports 2005 389,438

Armed Activities on the Territory of the Congo (Democratic Republic of the Congo v.

Uganda), Provisional Measures, 1 July 2000

Armed Activities on the Territory of the Congo (New Application: 2002) (Democratic

Republic of the Congo v. Rwanda), jurisdiction of the Court and admissibility of the application, Judgment of 3 February 2006, ICJ Reports 2006

Arrest Warrant of 11 April 2000 (Democratic Republic of the Congo v. Belgium), Judgment of

14 February 2002, ICJ Reports 2002

Barcelona Traction, Light and Power Company, Limited (New application: 1962) (Belgium v.

Spain), Second phase, Judgment of 5 February 1970, ICJ Reports 1970 ............... 130, 287

Certain Expenses of the United Nations (Article 17, paragraph 2, of the Charter), Advisory

Opinion of 20 July 1962, ICJ Reports 1962 435,444 
Corfu Channel (United Kingdom of Great Britain and Northern Ireland v. Albania), Judgment of 25 March 1948, ICJ Report 1948

Difference Relating to Immunity from Legal Process of a Special Rapporteur of the Commission on Human Rights, Advisory Opinion of 29 April 1999, ICJ Reports 1999

Gabčikovo-Nagymaros Project (Hungary/Slovakia), Judgment of 25 September 1997,

ICJ Report 1997

Legal Consequences for States of the Continued Presence of South Africa in Namibia (South West Africa) notwithstanding Security Council Resolution 276 (1970), Advisory Opinion of 21 June 1971, ICJ Report 1971 $287,444-5$

Legal Consequences for States of the Continued Presence of South Africa in Namibia (South West Africa) notwithstanding Security Council Resolution 276 (1970), Oral Statements and Correspondence: Declaration of President Zafrullah Khan, 21 June 1971, ICJ Report 1971

Legal Consequences of the Construction of a Wall in the Occupied Palestinian Territory, Advisory Opinion of 9 July 2004, ICJ Reports 2004 429, 435, 444-5

Legality of the Threat or Use of Nuclear Weapons Case, Advisory Opinion of 8 July 1996, ICJ Reports 1996 $57-8,230,261-3,444$

Legality of the Use by a State of Nuclear Weapons in Armed Conflict, Advisory Opinion of 8 July 1996, ICJ Reports 1996

Legality of Use of Force (Serbia and Montenegro v. Netherlands), Judgment of 15 December 2004, ICJ Reports 2004

Maritime Dispute (Peru v. Chile), Judgment of 27 January 2014, general list no. 137 .......... 434

Military and Paramilitary Activities in and against Nicaragua (Nicaragua v. United States of America), Jurisdiction and admissibility, ICJ Reports 1984 $11,13,59,86-7$

Military and Paramilitary Activities in and against Nicaragua (Nicaragua v. United States of America), Merits, Judgment of 27 June 1986, ICJ Reports 1986 $129,429,440-41$

Military and Paramilitary Activities in and against Nicaragua (Nicaragua v. United States of America), Preliminary Objections, 9 April 1984, ICJ Reports 1984

Nuclear Tests Case (New Zealand v. France), Judgment of 20 December 1974, ICJ Reports 1974

Obligations concerning Negotiations relating to Cessation of the Nuclear Arms Race and to Nuclear Disarmament (Marshall Islands v. United Kingdom), Preliminary Objections, Judgment of 5 October 2016, ICJ Reports 2016 $88-9,264$

Obligation to Negotiate Access to the Pacific Ocean (Bolivia v. Chile), Verbatim record, http://www.icj-cij.org/en/case/153/oral-proceedings (last accessed 2 April 2018) ....... 88-90

Pulp Mills on the River Uruguay (Argentina v. Uruguay), Judgment of 20 April 2010, ICJ Reports 201

Questions of Interpretation and Application of the 1971 Montreal Convention Arising from the Aerial Incident at Lockerbie (Libyan Arab Jamahiriya v. United States of America; Libyan Arab Jamahiriya v. United Kingdom), Judgment, Judgment of 27 February 1998, ICJ Reports 1998

Questions relating to the Obligation to Prosecute or Extradite (Belgium v. Senegal), Judgment of 20 July 2012, ICJ Reports 2012 429, 444

Questions Relating to the Seizure and Detention of Certain Documents and Data (Timor-Leste v. Australia), Request for the Indication of Provisional Measures, 17 December 2013, General List No. 156

Reparation for Injuries Suffered in the Service of the United Nations, Advisory Opinion of 11 April 1949, ICJ Reports 1949 435, 444-5

Serbia and Montenegro v. Belgium, Judgment of 15 December 2004, ICJ Reports 2004 ...... 438

Serbia and Montenegro v. Canada, Judgment of 15 December 2004, ICJ Reports 2004 ........ 438

Serbia and Montenegro v. France, Judgment of 15 December 2004, ICJ Reports 2004 ......... 438

Serbia and Montenegro v. Germany, Judgment of 15 December 2004, ICJ Reports 2004 ..... 438 
Serbia and Montenegro v. Italy, Judgment of 15 December 2004, ICJ Reports 2004 ............ 438

Serbia and Montenegro v. Portugal, Judgment of 15 December 2004, ICJ Reports 2004 ...... 438

Serbia and Montenegro v. United Kingdom, Provisional Measures, 2 June 1999, ICJ Reports 1999

United States Diplomatic and Consular Staff in Tehran (United States of America v. Iran), Judgment of 24 May 1980, ICJ Reports 1980

Western Sahara, Advisory opinion of 16 October 1975, ICJ Reports 1975 ........................ 444-5

Yugoslavia v. Spain, Provisional Measures, 2 June 1999, ICJ Reports 1999 ............................. 438

Yugoslavia v. United States of America, Provisional Measures, 2 June 1999, ICJ Reports 1999

\section{International Criminal Court}

Cengiz İnşaat v. Libya, 2016, pending

DS Construction v. Libya, 2016, pending

Etrak v. Libya, 2015, pending

General Dynamics v. Libya, Award issued on 5 January 2016

German Investor v. Libya, 2016, pending

Güriş İnşaat v. Libya, 2016, pending

Güriş İnşaat v. Syrian Arab Republic, 2016, pending 209,212

Nurol İnşaat I v. Libya, 2017, pending 212

Olin Holdings v. Libya, Award issued on 25 May 2018 211-12

Ozatlin v. Libya, 2016, discontinued

The Prosecutor v. Abdallah Banda Abakaer Nourain and Saleh, ICC-02/05-03/09-362-Anx 4

Situation in the Republic of Kenya, (Pre-trial Chamber II) ICC-01/09, 31 March 2009 ........ 178

Tekfen İnşaat I v. Libya, 2016, pending

Tekfen İnşaat II v. Libya, 2016, pending .

Turkish Investor v. Libya, 2016, pending

International Criminal Court - Assembly of State Parties

Negotiated Relationship Agreement between the International Criminal Court and the United Nations, ICC-ASP/3/Res.1, 7 September 2004

Strengthening the International Criminal Court and the Assembly of States Parties, UN Doc. ICC-ASP/12/Res.8, 27 November 2013

International Criminal Court - Office of The Prosecutor

Interests of Justice, (Policy Paper), September 2007

\section{International Tribunal of the Former Yugoslavia}

Prosecutor v. Dusko Tadic aka 'DULE', case IT-94-1-AR72, Decision on the Defence Motion for Interlocutory Appeal on Jurisdiction, 2 October 1995

\section{International Tribunal for the Law of the Sea}

The Mox Plant Case (Ireland v. United Kingdom) Case No. 10, Provisional Measures, Order of 3 December 2001 


\section{Permanent Court of Arbitration}

A Conciliation Commission Constituted Under Annex V of the 1982 United Nations Convention on the Law of the Sea (Timor Leste v. Australia), PCA Case No. 2016-10

Eritrea-Ethiopia Claims Commission, Final Award issued on 17 August 2009, PCA Case No. 2001-02

The Norwegian Shipowners' Claims (Norway v. US), Award of the Tribunal, 13 October 1922

The South China Sea Arbitration (The Republic of Philippines v. The People's Republic of China), award issued on 12 July 2016, PCA Case No. 2013-19

\section{PCA, UNCITRAL}

Aeroport Belbek LLC \& Mr. Igor Valerievich Kolomoisky v. The Russian Federation, 2015, pending

Everest Estate LLC \& Others v. The Russian Federation, Award issued on 1 May 2018 209-10

UNCITRAL, Limited Liability Co. Lugzor \& Others v. The Russian Federation, 2015, pending

Oschadbank v. The Russian Federation, 2015, pending 209

PJSC CB Privatbank \& Finance Co. Finilion LLC v. The Russian Federation, 2015, pending

PJSC Ukrnafta v. The Russian Federation, 2015, pending

Stabil LLC \& Others v. The Russian Federation, 2015, pending

Yosef Maiman \& Others v. Arab Republic of Egypt, Award issued on 9 February 2017

\section{Permanent Court of International Justice}

Factory at Chorzów (Germany v. Poland), Judgment No. 13 of 1928, Claim for Indemnity, Merits, P.C.I.J. Reports Series A, No. 17 (1928)

S.S. 'Lotus' (France v. Turkey), Judgment of 7 September 1927, P.I.C.J. Reports Series A, No. 10 (1927)

The Mavrommatis Palestine Concessions (Greece v. United Kingdom), Judgment of 30 August 1924, P.I.C.J. Reports Series A, No. 2 (1924)

\section{United Nations Commission on International Trade Law}

Agility Public Warehousing Co. K.S.C. v. Republic of Iraq, 2017, pending .......................... 209

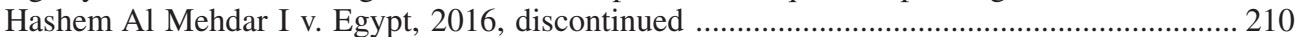

Hashem Al Mehdar II v. Egypt, 2016, discontinued .......................................................... 210

Hashem Al Mehdar III v. Egypt, 2016, discontinued ........................................................... 210

Intersema Bau A.G. v. Libya, Award issued on 24 August 2010 ............................................. 211

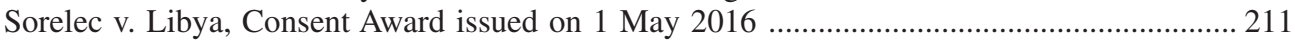

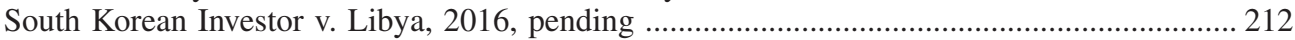

\section{World Trade Organization Dispute Settlement}

Argentina-Measures Relating to Trade in Goods and Services Dispute DS453, Appellate Body Report circulated 14 April 2016

Argentina-Transitional Safeguard Measures on Certain Imports of Woven Fabric Products of Cotton and Cotton Mixtures Originating in Brazil Dispute DS190, Mutually Agreed Solution notified 30 June 2000 ... 465, 467

Brazil-Certain Measures Concerning Taxation and Charges Dispute DS472, Panel Report circulated 30 August 2017 
Brazil-Export Financing Programme for Aircraft Dispute DS46, Second Recourse to Article 21.5 Panel Report circulated 26 July 2001

Canada - Continued Suspension of Obligations in the EC-Hormones Dispute DS321, Appellate Body Report circulated 16 October 2008 .............................................. 465-6

Canada-Measures Affecting the Export of Civilian Aircraft Dispute DS70, Article 21.5

Appellate Body Report circulated 21 July 2000 ... 465-6

Canada-Measures Affecting the Export of Civilian Aircraft Dispute DS71, Subsidies and

Countervailing Measures: Article 5, Request for Consultations received

10 March 1997 $465-6$

Canada-Measures Governing the Sale of Wine in Grocery Stores Dispute DS520, Request for

Consultations received 18 January 2017 ....................................................................... 474

Canada-Measures Governing the Sale of Wine in Grocery Stores (second complaint) Dispute

DS531, Request for Consultations received 28 September 2017 .................................... 474

Chile-Price Band System and Safeguard Measures Relating to Certain Agricultural Products

Dispute DS207, Article 21.5 Appellate Body Report circulated 7 May 2007 $465-8$

Chile-Price Band System and Safeguard Measures Relating to Certain Agricultural Products

Dispute DS220, Request for Consultations received 5 January 2001 $465-8$

China-Certain Measures Concerning the Protection of Intellectual Property Rights Dispute

DS542, Request for Consultations received 23 March 2018

China-Rare Earths (European Union v. China) Dispute DS432, Panel report circulated on

26 March 2014 $455,465-7$

China-Rare Earths (Japan v. China) Dispute DS433, Panel report circulated on

26 March 2014 $455,465-7$

China-Rare Earths (United States v. China) Dispute DS431, Panel report under appeal on

8 April 2014 $455,465-7$

China-Raw Materials (European Communities v. China) Dispute DS395, Implementation notified by respondent on 28 January 2013 $455,465-7$

China-Raw Materials (Mexico v. China) Dispute DS398, Implementation notified by respondent on 28 January 2013 $455,465-7$

China-Raw Materials (United States v. China) Dispute DS394, Implementation notified by respondent on 28 January 2013 $455,465-7$

Colombia-Measures Relating to the Importation of Textiles, Apparel and Footwear Dispute

DS461, Article 21.3(c) Arbitration Report circulated 15 November 2016 .................. 465-6

Dominican Republic-Foreign Exchange Fee Affecting Imports from Costa Rica Dispute

DS333, Request for Consultations received 12 September 2005 465,467

European Communities-Conditions for the Granting of Tariff Preferences to Developing Countries Dispute DS246, Article 21.3(c) Arbitration Report circulated

20 September 2004 $464-8$

European Communities-Export Subsidies on Sugar Dispute DS265, Article 21.3(c)

Arbitration Report circulated 28 October 2005 .................................................... 465-6

European Communities-Export Subsidies on Sugar Dispute DS266, Article 21.3(c)

Arbitration Report circulated 28 October 2005 $465-6$

European Communities-Export Subsidies on Sugar Dispute DS283, Article 21.3(c) Arbitration Report circulated 28 October 2005 $465-6$

European Communities-Generalized System of Preferences Dispute DS242, Request for

Consultations received 7 December 2001 $465-8$

European Communities-Measures Affecting Differential and Favourable Treatment of Coffee Dispute DS154, Request for Consultations received 7 December 1998 .......... 465-8

European Communities-Measures Affecting Soluble Coffee Dispute DS209, Request for

Consultations received 12 October 2000 $465-8$

European Communities-Measures Affecting the Approval and Marketing of Biotech

Products Dispute DS291, Panel Report circulated 29 September 2006 465, 467-8 
European Communities-Measures Affecting the Approval and Marketing of Biotech Products Dispute DS292, Mutually Agreed Solution notified 15 July 2009 465, 467-8

European Communities-Measures Affecting the Approval and Marketing of Biotech Products Dispute DS293, Panel Report circulated 29 September 2006 $465,467-8$

European Communities - Measures Affecting Trade in Large Civil Aircraft Dispute DS316,

Article 21.5 Appellate Body Report circulated 15 May 2018 465-6

European Communities-Measures Concerning Meat and Meat Products (Hormones) Dispute

DS26, Recourse to Article 22.6 Arbitration Report circulated 12 July 1999 ............... 465-6

European Communities-Measures Concerning Meat and Meat Products (Hormones) Dispute

DS48, Recourse to Article 22.6 Arbitration Report circulated 12 July 1999 $465-6$

European Communities-Regime for the Importation of Bananas Dispute DS361, Request for

Consultations received 21 March 2007 $465-6$

European Communities-Regime for the Importation of Bananas Dispute DS364, Request for Consultations received 22 June 2007 $465-6$

European Communities-Regime for the Importation, Sale and Distribution of Bananas

Dispute DS16, Request for Consultations received 28 September 1995 $465-6$

European Communities-Regime for the Importation, Sale and Distribution of Bananas

Dispute DS27, Article 21.5 Appellate Body Report (United States) circulated

26 November 2008 $465-6$

European Communities-Regime for the Importation, Sale and Distribution of Bananas

Dispute DS105, Request for Consultations received 24 October 1997 ...................... 465-6

European Communities-Regime for the Importation, Sale and Distribution of Bananas

Dispute DS158, Request for Consultations received 20 January 1999 ........................ 465-6

European Union and its Member States-Certain Measures Relating to the Energy Sector

Dispute DS476, Request for Consultations received 30 April 2014

European Union-Cost Adjustment Methodologies and Certain Anti-Dumping Measures on

Imports from Russia Dispute DS474, Request for Consultations received

23 December 2013

European Union-Cost Adjustment Methodologies and Certain Anti-Dumping Measures on

Imports from Russia-(Second complaint) Dispute DS494, Request for Consultations received 7 May 2015

European Union-Measures on Atlanto-Scandian Herring Dispute DS469, Request for

Consultations received 4 November 2013 $465-7$

India-Export Related Measures Dispute DS541, Request for Consultations received

14 March 2018

India-Import Restrictions Dispute DS149, Request for Consultations received

28 October 1998 $465,467-8$

India-Import Restrictions Maintained Under the Export and Import Policy 2002-2007

Dispute DS279, Request for Consultations received 23 December 2002 .......... 465, 467-8

India-Measures Affecting the Automotive Sector Dispute DS146, Appellate Body Report circulated 19 March 2002

India-Measures Affecting Trade and Investment in the Motor Vehicle Sector Dispute DS175,

Appellate Body Report circulated 19 March 2002 465-6

India-Measures Concerning the Importation of Certain Agricultural Products Dispute DS430,

Appellate Body Report circulated 4 June 2015

India-Quantitative Restrictions on Imports of Agricultural, Textile and Industrial Products

Dispute DS90, Mutually Agreed Solution notified 14 January 1999

India-Quantitative Restrictions on Imports of Agricultural, Textile and Industrial Products

Dispute DS91, Mutually Agreed Solution notified 23 April 1998

India-Quantitative Restrictions on Imports of Agricultural, Textile and Industrial Products

Dispute DS92, Mutually Agreed Solution notified 3 April 1998 465

India-Quantitative Restrictions on Imports of Agricultural, Textile and Industrial Products

Dispute DS93, Mutually Agreed Solution notified 11 December 1998 465 
India-Quantitative Restrictions on Imports of Agricultural, Textile and Industrial Products Dispute DS94, Mutually Agreed Solution notified 23 March 1998 465

India-Quantitative Restrictions on Imports of Agricultural, Textile and Industrial Products Dispute DS96, Mutually Agreed Solution notified 6 May 1998 465

Indonesia - Importation of Horticultural Products, Animals and Animal Products Dispute DS455, Request for Consultations received 10 January 2013 ..................................... 465-7

Indonesia-Importation of Horticultural Products, Animals and Animal Products Dispute DS465, Request for Consultations received 30 August 2013 ....................................... 465-7

Indonesia-Importation of Horticultural Products, Animals and Animal Products Dispute DS466, Request for Consultations received 30 August 2013 $465-7$

Kazakhstan-Anti-dumping Measures on Steel Pipes Dispute DS530, Request for Consultations received 19 September 2017

Korea-Measures Affecting Trade in Commercial Vessels Dispute DS273, Panel Report circulated 7 March 2005

Russia-Measures affecting the importation of railway equipment and parts thereof Dispute DS499, Request for Consultations received 21 October 2015

Russia-Measures Concerning the Importation and Transit of Certain Ukrainian Products Dispute DS532, Request for Consultations received 13 October 2017

Russia-Measures Concerning Traffic in Transit Dispute DS512, Request for Consultations received 14 September 2016

Russia-Tariff Treatment of Certain Agricultural and Manufacturing Products Dispute DS485, Panel Report circulated 12 August 2016

Ukraine-Anti-Dumping Measures on Ammonium Nitrate Dispute DS493, Request for Consultations received 7 May 2015

Ukraine-Measures relating to Trade in Goods and Services Dispute DS525, Request for Consultations received 19 May 2017

United Arab Emirates-Measures Relating to Trade in Goods and Services, and Trade-Related Aspects of Intellectual Property Rights Dispute DS526, Request for Consultations received 31 July 2017

United States-Anti-Dumping Act of 1916 Dispute DS136, Recourse to Article 22.6 Arbitration Report circulated 24 February 2004

United States-Anti-Dumping Act of 1916 Dispute DS162, Article 21.3(c) Arbitration Report circulated 28 February 2001 465,467

United States-Anti-Dumping and Countervailing Duties on Certain Products and the Use of Facts Available Dispute DS539, Request for Consultations received 14 February 2018

United States-Anti-Dumping Measures Applying Differential Pricing Methodology to Softwood Lumber from Canada Dispute DS534, Request for Consultations received 28 November 2017

United States-Anti-Dumping Measures on Fish Fillets from Vietnam Dispute DS536, Request for Consultations received 8 January 2018

United States-Certain Measures Concerning Pangasius Seafood Products from VietNam, Dispute DS540, Request for Consultations received 22 February 2018

United States-Certain Measures on Steel and Aluminium Products Dispute DS544, Request for Consultations received 5 April 2018

United States-Certain Measures on Steel and Aluminium Products Dispute DS547, Request for Consultations received 18 May 2018

United States-Certain Measures on Steel and Aluminium Products Dispute DS548, Request for Consultations received 1 June 2018

United States-Certain Measures on Steel and Aluminium Products Dispute DS550, Request for Consultations received 1 June 2018

United States-Certain Measures on Steel and Aluminium Products Dispute DS551, Request for Consultations received 5 June 2018 
United States-Certain Measures on Steel and Aluminium Products Dispute DS552, Request

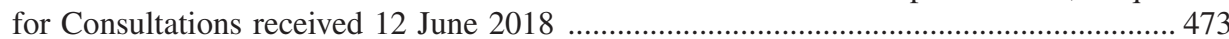

United States-Certain Systemic Trade Remedies Measures Dispute DS535, Request for Consultations received 20 December 2017

United States-Continued Dumping and Subsidy Offset Act of 2000 Dispute DS217, Recourse to Article 22.6 Arbitration Report circulated 31 August 2004 ................ 465, 467

United States-Continued Dumping and Subsidy Offset Act of 2000 Dispute DS234, Recourse to Article 22.6 Arbitration Report circulated 31 August 2004 ................. 465, 467

United States-Continued Suspension of Obligations in the EC-Hormones Dispute, Dispute DS320, Appellate Body Report circulated 16 October 2008 .......................... 465-6

United States-Countervailing and Anti-dumping Measures on Certain Products from China Dispute DS449, Appellate Body Report circulated 7 July 2014

United States-Countervailing Duty Measures on Certain Products from China Dispute DS437, Article 21.5 Panel Report circulated 21 March 2018

United States-Countervailing Measures on Certain Pipe and Tube Products (Turkey) Dispute DS523, Request for Consultations received 8 March 2017

United States-Countervailing Measures on Softwood Lumber from Canada Dispute DS533, Request for Consultations received 28 November 2017

United States-Definitive Safeguard Measures on Imports of Certain Steel Products Dispute DS248, Appellate Body Report circulated 10 November 2003 465-6, 468

United States-Definitive Safeguard Measures on Imports of Certain Steel Products Dispute DS249, Appellate Body Report circulated 10 November 2003 465-6, 468, 473

United States-Definitive Safeguard Measures on Imports of Certain Steel Products Dispute DS251, Appellate Body Report circulated 10 November 2003. 465-6, 468, 473

United States-Definitive Safeguard Measures on Imports of Certain Steel Products Dispute DS252, Appellate Body Report circulated 10 November 2003 465-6, 468, 473

United States-Definitive Safeguard Measures on Imports of Certain Steel Products Dispute DS253, Appellate Body Report circulated 10 November 2003 465-6, 468, 473

United States-Definitive Safeguard Measures on Imports of Certain Steel Products Dispute DS254, Appellate Body Report circulated 10 November 2003. 465-6, 468, 473

United States-Definitive Safeguard Measures on Imports of Certain Steel Products Dispute DS258, Appellate Body Report circulated 10 November 2003 465-6, 468, 473

United States-Definitive Safeguard Measures on Imports of Certain Steel Products Dispute DS259, Appellate Body Report circulated 10 November 2003 465-6, 468, 473

United States-Import Prohibition of Certain Shrimp and Shrimp Products Dispute DS58, Article 21.5 Appellate Body Report circulated 22 October 2001 .................................. 467

United States-Import Prohibition of Certain Shrimp and Shrimp Products Dispute DS61, Request for Consultations received 25 October 1996 467

United States-Measures Affecting the Importation of Animals, Meat and Other Animal Products from Argentina Dispute DS447, Panel Report circulated 24 July 2015 ....... 465-6

United States-Measures Affecting the Importation of Fresh Lemons Dispute DS448, Request for Consultations received 3 September 2012 $465-6$

United States - Measures Affecting Trade in Large Civil Aircraft Dispute DS353, Article 21.5 Panel Report circulated 9 June 2017 $459,465-6$

United States-Measures Relating to Zeroing and Sunset Reviews Dispute DS322, Article 21.5 Appellate Body Report circulated 18 August 2009 465,467

United States-Safeguard measure on imports of crystalline silicon photovoltaic products Dispute DS545, Request for Consultations received 14 May 2018 474

United States-Safeguard measure on imports of large residential washers Dispute DS546, Request for Consultations received 14 May 2018

United States-Section 211 Omnibus Appropriations Act of 1998 Dispute DS176, Appellate Body Report circulated 2 January 2002 464-5, 467 
United States-Sections 301-310 of the Trade Act 1974 Dispute DS152, Panel Report circulated 22 December 1999 $465,467-8$

United States-Subsidies on Upland Cotton Dispute DS267, Recourse to Article 22.6 Arbitration Report circulated 31 August 2009 $465-6$

United States-Tariff Increases on Products from the European Communities Dispute DS39, Request for Consultations received 18 April 1996 465-6

United States-Tariff Measures on Certain Goods from China Dispute DS543, Request for Consultations received 4 April 2018 474

United States-The Cuban Liberty and Democratic Solidarity Act Dispute DS38, Request for Consultations received 3 May 1996 464-5, 467

WTO Dispute Settlement Body (DSB) on 17 December 2012, WTO Doc. WT/DSB/M/327 457

WTO Dispute Settlement Body (DSB) on 25 January 2016, WTO Doc. WT/DSB/M/373 .... 457

WTO Dispute Settlement Body (DSB) on 23 May 2016, WTO Doc. WT/DSB/M/379 457,459

WTO Dispute Settlement Body (DSB) on 22 June 2016, WTO Doc. WT/DSB/M/380 ......... 457

WTO Dispute Settlement Body (DSB) on 23 November 2016, WTO Doc. WT/DSB/M/389 457,470

WTO Dispute Settlement Body (DSB) on 27 February 2017, WTO Doc. WT/DSB/M/391 458

WTO Dispute Settlement Body (DSB) on 20 February 2017, WTO Doc. WT/DSB/M/392 458,470

WTO Dispute Settlement Body (DSB) on 21 March 2017, WTO Doc. T/DSB/M/394 ........ 458

WTO Dispute Settlement Body (DSB) on 19 April 2017, WTO Doc. T/DSB/M/396 ........... 458

WTO Dispute Settlement Body (DSB) on 22 May 2017, WTO Doc. WT/DSB/M/397 ......... 458

WTO Dispute Settlement Body (DSB) on 19 June 2017, WTO Doc. T/DSB/M/398 ............ 458

WTO Dispute Settlement Body (DSB) on 20 July 2017, WTO Doc. WT/DSB/M/399 ......... 458

WTO Dispute Settlement Body (DSB) on 31 August 2017, WTO Doc. T/DSB/M/400 ........ 458

WTO Dispute Settlement Body (DSB) on 23 October 2017, WTO Doc.

WT/DSB/M/403 458,471

WTO Dispute Settlement Body (DSB) on 22 November 2017, WTO Doc.

WT/DSB/M/404 $458,471-2$

WTO Dispute Settlement Body (DSB) on 22 January 2018, WTO Doc. WT/DSB/M/407 .... 458

WTO Dispute Settlement Body (DSB) on 28 February 2018, WTO Doc.

WT/DSB/M/409 458

WTO Dispute Settlement Body (DSB) on 8 May 2017, WTO Doc. WT/DSB/W/596 ........... 458

WTO Dispute Settlement Body (DSB) on 11 May 2017, WTO Doc. T/DSB/W/597 ............ 458

WTO Dispute Settlement Body (DSB) on 9 November 2017, WTO Doc. WT/DSB/W/609 458,474

\section{National}

\section{Australia}

Federal Court

Zolfagharkani v. Canada (Minister of Employment and Immigration) [1993] 3 F.C. 540 ...... 313 


\section{Costa Rica}

\section{Constitutional Court}

Luis Roberto Zamora Bolaños v. Ministerio de Salud, Case No. 2008-14193, Judgment of 8 September 2008 p. 406 n51, 407 n52 $504-5$

Luis Roberto Zamora Bolaños v. Ministerio de Relaciones Exteriores y Otro, Case No. 2004-9992, Judgment of 2004 p. 406 n50 504

\section{France}

Commission des recours des réfugiés

Zein El Abiddine, Judgment of 13 June 1985

Taha, Judgment of 30 October 1989

\section{Japan}

Nagoya High Court

Mōri v. Japan, Judgment of April 27, 2008 (unpublished decision) p. 406 n49 504

\section{Sapporo District Court}

Ito v. Minister of Agriculture and Forestry, Judgment of 7 September 1973 p. 406 n48 _... 503-4

\section{Korea}

\section{Constitutional Court}

Case Concerning the Presidential Decision to Dispatch Korean National Armed Forces to Iraq, 16-1 KCCR 601, 2003Hun-Ma814, Judgment of 29 April 2004 p. 407 n53 505

\section{Peru}

\section{The Peruvian Truth and Reconciliation Commission}

(Comisión de la Verdad y Reconciliación, CVR), CVR, The 9-vol. Final Report (28 August 2003), see http://cverdad.org.pe/ifinal/ (accessed 12 November 2014)

\section{United Kingdom}

\section{Court of Appeal}

Krotov v. Secretary of State for the Home Department, [2004] EWCA Civ. 69, Judgment of 11 February 2004

\section{House of Lords}

Sepet (FC) and another (FC) v. Secretary of State for the Home Department [2003] 1 W.L.R. 856, Judgment of 20 March 2003 p. 257, 258 n31

R v. Secretary of State for the Home Department, ex parte Adan [1998] UKHL 15, Judgment of 2 April 1998 Lord Slynn of Hadley

\section{United States}

MA v. INS, 899 F.2d 304, 313, 4th Cir. 1990 
Protect Our Defenders and the Connecticut Veterans Center v. Department of Defense and Department of Homeland Security, 17 CV 02072, filed 13 December 2017, paragraph 29 of the Complaint

SWAN v. Mattis, 12 CV 06006, filed 18 December 2017,

https://www.aclu.org/sites/default/files/field_document/

e-filed_second_amended_complaint_swan_v._mattis.pdf (accessed

15 January 2018)

Board of immigration appeals

In re H-, 21 I. \& N. Dec. 337, Interim Decision No. 3276 of 30 May 1996, [1996] WL 291910

\section{Supreme Court}

Korematsu v. United States, 323 U.S. 214, Judgment of 18 December 1944

\section{DECISIONS OF INTERGOVERNMENTAL AND OTHER ORGANIZATIONS}

\section{Security Council}

Security Council, 18 May 2011, Letter dated 12 May 2011 from the President of the International Tribunal for the Prosecution of Persons Responsible for Serious Violations of International Humanitarian Law Committed in the Territory of the Former Yugoslavia since 1991, addressed to the President of the Security Council, UN Doc.

$\mathrm{S} / 2011 / 316$

Security Council Report of 9 February 2017 Can the Security Council Prevent Conflict? http://www.securitycouncilreport.org/atf/cf/\%7B65BFCF9B-6D27-4E9C-8CD3-

CF6E4FF96FF9\%7D/research_report_conflict_prevention_2017.pdf (accessed 10 January 2018)

SC Res. 39 (1948) of 20 January 1948, The India-Pakistan Question, UN Doc. S/654 ........ 359,

SC Res. 47 (1948) of 21 April 1948, The India-Pakistan Question, UN Doc. S/726 ….......... 359

SC Res. 50 (1948) of 29 May 1948, The Palestine Question, UN Doc. S/801 ....................... 359

SC Res. 186 (1964) of 4 March 1964, The Cyprus Question, UN Doc. S/RES/186, op. clause 5

SC Res. 221 (1966) of 9 April 1966 Question concerning the situation in Southern Rhodesia

SC Res. 232 (1966) of 16 December 1966 Southern Rhodesia

SC Res. 307 (1971) of 21 December 1971, The India/Pakistan Subcontinent, UN Doc. S/RES/307

SC Res. 350 (1974) of 31 May 1974, Israel-Syrian Arab Republic, UN Doc. S/RES/350 .... 359

SC Res. 359 (1974) of 15 August 1974, Cyprus, UN Doc. S/RES359

SC Res. 425 (1978) of 19 March 1978, Israel-Lebanon, UN Doc. S/RES/425 $359-60$

SC Res. 687 (1991) of 3 April 1991 Iraq-Kuwait

SC Res. 688 (1991) of 5 April 1991 Iraq

SC Res. 690 (1991) of 29 April 1991, Western Sahara, UN Doc. S/RES/690 $360-61$

SC Res. 745 (1992) of 28 February 1992, Cambodia, UN Doc. S/RES/745 361

SC Res. 827 (1993) of 25 May 1993 International Criminal Tribunal for the former Yugoslavia $386,388,428,430$

SC Res. 836 (1993) of 4 June 1993 Republic of Bosnia and Herzegovina ICTY 119 


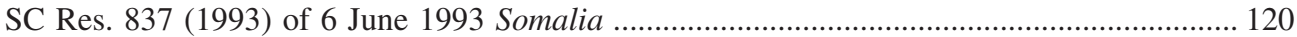

SC Res. 942 (1994) of 23 September 1994 Bosnia and Herzegovina .................................... 120

SC Res. 955 (1994) of 8 November 1994, International Criminal Tribunal for Rwanda

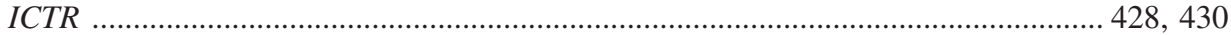

SC Res. 1208 (1998) of 19 November 1998 on the maintenance of the security and civilian and humanitarian character of refugee camps and settlements in Africa, UN Doc. S/RES/1208(1998)

SC Res. 1244 (1999) of 10 June 1999 on the deployment of international civil and security

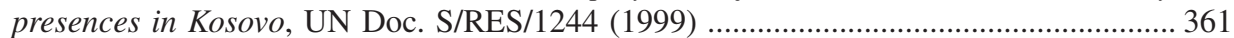

SC Res. 1272 (1999) of 25 October 1999, Timor, UN Doc. S/RES/1272 ............................... 361

SC Res. 1296 (2000) of 19 April 2000 on protection of civilians in armed conflict, UN Doc. S/RES/1296 (2000)

SC Res. 1325 (2000) of 31 October 2000 on women and peace and security, UN Doc. S/RES/1325 20, 320-21, 340-42, 344-5, 350

SC Res. 1509 (2003) of 19 September 2003, on establishment of the UN Mission in Liberia (UNMIL), UN Doc. S/RES/1509

SC Res. 1542 (2004) of 30 April 2004, on establishment of the UN Stabilization Mission in Haiti (MINUSTAH), UN Doc. S/RES/1542

SC Res. 1593 (2005) of 31 March 2005 on violations of international humanitarian law and human rights law in Darfur, Sudan, UN Doc. S/ RES/1593 $380,389,436$

SC Res. 1674 (2006) of 28 April 2006, on protection of civilians in armed conflict, UN Doc. S/RES/1674 $147,360,387,390$

SC Res. 1701 (2006) of 11 August 2006, on full cessation of hostilities in Lebanon and on extending and strengthening the mandate of the UN Interim Force in Lebanon (UNIFIL) to monitor the ceasefire, UN Doc. S/RES/1701

SC Res. 1769 (2007) of 31 July 2007, on establishment of AU/UN Hybrid Operation in Darfur (UNAMID), UN Doc. S/RES/1769

SC Res. 1888 (2009) of 30 September 2009 on acts of sexual violence against civilians in armed conflicts, UN Doc. S/RES/1888 340, 342, 344-5

SC Res. 1889 (2009) of 5 October 2009 on women and peace and security, UN Doc. S/RES/1889 $340,347,349$

SC Res. 1894 (2009) of 11 November 2009 on the protection of civilians in armed conflict, UN Doc. S/RES/1894 354, 385-6

SC Res. 1908 (2010) of 19 January 2010, on increasing the overall force levels of the UN Stabilization Mission in Haiti to support the immediate recovery, reconstruction and stability efforts, UN Doc. S/RES/1908

SC Res. 1911 (2010) of 28 January 2010 on extension of the mandate of the UN Operation in Côte d'Ivoire (UNOCI), UN Doc. S/RES/1911

SC Res. 1925 (2010) of 28 May 2010 Democratic Republic of the Congo, UN Doc. S/RES/1925

SC Res. 1927 (2010) of 4 June 2010, on the composition of the military and police components of the UN Stabilization Mission in Haiti (MINUSTAH), UN Doc. S/RES/1927

SC Res. 1960 (2010) of 16 December 2010 on women and peace and security, UN Doc. S/RES/1960 340,345

SC Res. 1970 (2011) 26 February 2011 on establishment of a Security Council Committee to monitor implementation of the arms embargo against the Libyan Arab Jamahiriya, UN Doc. S/RES/1970 $381,388,398,436$

SC Res. 1973 (2011) of 17 March 2011 on the situation in the Libyan Arab Jamahiriya, UN Doc. S/RES/1973(2011) $119,354,398$

SC Res. 1990 (2011) of 27 June 2011, on establishment of the UN Interim Security Force for Abyei (UNISFA), UN Doc. S/RES/1990 
SC Res. 1996 (2011) of 8 July 2011 Republic of South Sudan, UN Doc. S/RES/1996 119,362

SC Res. 2053 (2012) of 27 June 2012, on extension of the mandate of the UN Organization Stabilization Mission in the Democratic Republic of the Congo (MONUSCO), UN Doc. S/RES/2053

SC Res. 2066 (2012) of 17 September 2012, on extension of the mandate of the UN Mission in Liberia (UNMIL) until 30 September 2013, UN Doc. S/RES/2066 362

SC Res. 2070 (2012) 12 October 2012, on extension of the mandate of the UN Stabilization Mission in Haiti (MINUSTAH), UN Doc. S/RES/2070

SC Res. 2098 (2013) of 28 March 2013, on extension of the mandate of the UN Organization Stabilization Mission in the Democratic Republic of the Congo (MONUSCO), UN Doc. S/RES/2098

SC Res. 2100 (2013) of 25 April 2013, on establishment of the UN Multidimensional Integrated Stabilization Mission in Mali (MINUSMA), UN Doc. S/RES/2100

SC Res. 2112 (30 July 2013), on extension of the mandate of UN Operation in Côte d'Ivoire (UNOCI) until 30 June 2014, UN Doc. S/RES/2112

SC Res. 2122 (2013) of 18 October 2013, on women and peace and security, UN Doc. S/RES/2122 $340,342-5,348,350$

SC Res. 2147 (2014) of 28 March 2014, on the extension of the Mandate UN Stabilization Mission in the Democratic Republic of the Congo (MONUSCO), UN Doc. S/RES/2147

SC Res. 2149 (2014) of 10 May 2014, on establishment of the UN Multidimensional Integrated Stabilization Mission in the Central African Republic (MINUSCA) until 30 April 2015, UN Doc. S/RES/2149 362

SC Res. 2155 (2014) of 27 May 2014, on extension of the mandate of the UN Mission in South Sudan (UNMISS) until 30 November 2014, UN Doc. S/RES/2155 362

SC Res. 2171 (2014) of 21 August 2014 on the maintenance of international peace and security-Conflict prevention, UN Doc. S/RES/2171

SC Res. 2242 (2015) of 13 October 2015, on women and peace and security, UN Doc. $\mathrm{S} / \mathrm{RES} / 2242$ $340,342,345$

SC Res. 2282 (2016) of 27 April 2016, on post-conflict peacebuilding, UN Doc. S/RES/2282

SC Res. 2327 (2016) of 16 December 2016, Reports of the Secretary-General on the Sudan and South Sudan, UN Doc. S/RES/ 2327

SC Res. 2348 (2017) of 31 March 2017, on extension of the mandate of the UN Organization Stabilization Mission in the Democratic Republic of the Congo (MONUSCO) until 31 March 2018, UN Doc. S/RES/ 2348

SC Res. 2350 (2017) of 13 April 2017, on final extension of the mandate of the UN Stabilization Mission in Haiti (MINUSTAH), UN Doc. S/RES/2350 363

SC Res. 2363 (2017) of 29 June 2017, Reports of the Secretary-General on the Sudan and South Sudan, UN Doc. S/RES/ 2363

SC Res. 2364 (2017) of 29 June 2017, on extension of the mandate of the UN Multidimensional Integrated Stabilization Mission in Mali (MINUSMA) until 30 June 2018, UN Doc. S/RES/2364

SC Res. 2386 (2017) of 15 November 2017, on extension of the mandate of the UN Interim Security Force for Abyei (UNISFA) until 15 May 2018, UN Doc. S/RES/ 2386

SC Res. 2387 (2017) of 15 November 2017, on extension of the mandate of the UN Multidimensional Integrated Stabilization Mission in the Central African Republic (MINUSCA) until 15 November 2018, UN Doc. S/RES/ 2387 


\section{UN General Assembly}

UNGA A/C.3/71/L.29 (31 October 2016), Declaration on the Right to Peace, UN Doc. A/C.3/71/L.29

UNGA A/S-10/4 (23 May to 30 June 1978), Resolution and Decisions adopted by the General Assembly during its Tenth Special Session, UN Doc. A/S-10/4

UNGA (23 May 2005), In Larger Freedom: Towards Development, Security and Human Rights for All, Report of the Secretary-General: addendum: Peacebuilding Commission: explanatory note by the Secretary-General, UN Doc. A/59/2005/Add.2,

UNGA Res. 1 (24 January 1946), Establishment of a Commission to Deal with the Problems Raised by the Discovery of Atomic Energy, UN Doc. A/Res/1(I)

UNGA Res. 147 (16 December 2005), Basic Principles and Guidelines on the Right to a Remedy and Reparation for Victims of Gross Violations of International Human Rights Law and Serious Violations of International Humanitarian Law, UN Doc.

A/Res/60/147 $405-407$

UNGA Res. 189 (2 February 2017), Declaration on the Right to Peace, UN Doc. A/Res/71/189 14, 51, 69-70, 74-82, 97-8, 141, 164, 491

Preamble, 70

Art 1, 70-72, 183

Art 2, 71, 288, 305

Art 3, 72-3

Art 4, 73-4

Art 5, 74-5

UNGA Res. 290(IV) (1 December 1949), Essentials of Peace, UN Doc. A/RES/290(IV) 96,440

UNGA Res. 337 (3 November 1950), Uniting for Peace, UN Doc. A/RES/337(V) 435

UNGA Res. 428 (V) (14 December 1950), Statute of the Office of the United Nations High Commissioner for Refugees, annex, 5 UN GAOR Supp. (No. 20) 46, UN Doc. A/177

UNGA Res. 1653 (XVI) (24 November 1961), Declaration on the Prohibition of the use of Nuclear and Thermo-nuclear Weapons, UN Doc. A/Res/1653(XVI) 254-5

UNGA Res. 2028 (XX) (19 November 1965), Non-Proliferation of Nuclear Weapons, UN Doc. A/Res/2028(XX) 256

UNGA Res. 2312 (XXII) (14 December 1967), Declaration on Territorial Asylum, UN Doc. A/RES/2312(XXII)

UNGA Res. 2374 (XXV) (16 December 1970), The Declaration on the Strengthening of International Security, UN Doc. A/RES/25/2734

UNGA Res. 2625 (24 October 1970), Preamble Declaration on Principles of International Law concerning Friendly Relations and Cooperation among States in accordance with the Charter of the United Nations, UN Doc. A/RES/25/2625 ..... 69, 56-8, 84-5, 119, 127 ,

UNGA Res. 3201 (S-VI) (1 May 1974), Declaration on the Establishment of a New International Economic Order, UN Doc. A/RES/3201(S-VI)

UNGA Res. 3314 (XXIX) (14 December 1974) Definition of Aggression, UN Doc. A/RES/3314(XXIX) $58,136,440$

UNGA Res. 34/180 (1980) Convention on the Elimination of all forms of Discrimination Against Women, UN Doc. A/34/46; 1249 UNTS 13; 19 ILM 33

UNGA Res. $35 / 55$ (5 December 1980) Establishment of the University of Peace, UN Doc. A/RES/35/55

UNGA Res. 37/10 (15 November 1982) Manila Declaration on the Peaceful Settlement of Disputes, UN Doc. A/RES/37/590 
UNGA Res. 377 (V) (3 November 1950), Uniting for Peace, UN Doc. A/RES/377(V), available at: http://research.un.org/en/docs/ga/quick/emergency 96

UNGA Res. 39/11 (12 November 1984), Declaration on the Right of Peoples to Peace, UN Doc. A/RES/39/11 (1984) $66,97,137-8$

UNGA Res. 39/163 (17 December 1984), Charter of Economic Rights and Duties of States: Resolution Adopted by the General Assembly, UN Doc. A/RES/39/163 58

UNGA Res. 41/123 (4 December 1986), Measures of Assistance Provided to South African and Namibian Refugee Women and Children, UN Doc. A/RES/41/123(1986)

UNGA Res. 48/134 (20 December 1993), National Institutions for the Promotion and Protection of Human Rights, UN Doc. A/RES/48/134

UNGA Res. 50/50 (11 December 1995), UN Model Rules for the Conciliation of Disputes Between States, UN Doc. A/RES/50/50

UNGA Res. 53/243 (6 October 1999), Declaration on a Culture of Peace, UN Doc. A/RES/53/243

UNGA Res. 54/4, Optional Protocol to the Convention on the Elimination of Discrimination Against Women Annex, UN Doc. A/54/49 (Vol. I); 2131 UNTS 83

UNGA Res. 57/216 (27 February 2003), Promotion of the Right of Peoples to Peace, UN Doc. A/RES/25/216 (2003) .66, 97, 137

UNGA Res. 60/1 (25 October 2005), 2005 World Summit Outcome, UN Doc. A/RES/60/1(2005) $71,122,130-32,137,429,437-8,441$

UNGA Res. 60/163 (16 December 2005), Promotion of Peace as a Vital Requirement for the Full Enjoyment of all Human Rights by all, UN Doc. A/RES/60/163

UNGA Res. 63/189 (18 March 2009), Promotion of a Democratic and Equitable International Order, UN Doc. A/RES/63/189 (2009) $66,97,137$

UNGA Res. 63/308 (7 October 2009), The Responsibility to Protect, UN Doc. A/RES/63/308

UNGA Res. 65/283 (July 2011), Strengthening the Role of Mediation in the Peaceful Settlement of Disputes, Conflict Prevention and Resolution, UN Doc. A/RES/65/283 ..... 96

UNGA Res. 66/99 (2011), Draft Articles on the Effects of Armed Conflicts on Treaties, with Commentaries, UN Doc. A/RES/66/99

UNGA Res. 67/234 B (2 April 2013), The Arms Trade Treaty (ATT), UN Doc. A/Res/67/234 B 19-20, 267, 269-79, 282-3

Art 1, 269-70

Art 2, 275, 278

Art 3, 275

Art 4, 275

Art 5, 275

Art 6, 275-6, 278

Art 6(1), 275-6, 278

Art 6(2), 276

Art 6(3), 276, 278-80

Art 7, 275-9

Art 7(1), 276, 279

Art 7(3), 276-7, 279-80

Art 7(4), 277

UNGA Res. 70/1 (25 September 2015), Transforming our World: The 2030 Agenda for Sustainable Development, UN Doc. A/RES/70/1 163,184

UNGA Res. 71/189 (19 December 2016), Declaration on the Right to Peace, UN Doc. A/RES/71/189

Preamble, 70

Art 1, 70-72, 183

Art 2, 71, 288, 305

Art 3, 72-3 
Art 4, 73-4

Art 5, 74-5

\section{Human Rights Committee}

General Comment No. 11 'Prohibition of propaganda for war and inciting national, racial or religious hatred (Article 20)', UN Doc. HRI/GEN/1/Rev.6 at 133 (2003)

General Comment No. 22 'The right to freedom of thought, conscience and religion (Article

18)', UN Doc. CCPR/C/21/Rev.1/Add.4 (30 July 1993) 295-6

\section{Human Rights Council}

HRC Res. 8/9 (18 June 2008), Promotion on the People's Right to Peace, UN Doc. A/HRC/RES/8/9

HRC Res. 11/4 (17 June 2009), Promotion on the People's Right to Peace, UN Doc. A/HRC/RES/11/4

HRC Res. 14/3 (23 June 2010), Promotion on the Right of Peoples to Peace, UN Doc. A/HRC/RES/14/3

HRC Res. 32/9 (18 July 2016), on Human Rights and International Solidarity, UN Doc. A/HRC/RES/32/9

HRC Res. 35/4 (22 June 2017), on Promotion of the Right to Peace, UN Doc. A/HRC/RES/35/4

HRC Res. 35/10 (12 July 2017), on Accelerating Efforts to Eliminate Violence Against Women: Engaging Men and Boys in Preventing and Responding to Violence Against All Women and Girls, UN Doc. A/HRC/RES/35/10

HRC Res. 36/5 (4 October 2017), on Unaccompanied Migrant Children and Adolescents and Human Rights, UN Doc. A/HRC/RES/36/5

HRC Res. 36/9 (6 October 2017), on The Right to Development, UN Doc. A/HRC/RES/36/9

HRC Res. 37/13 (9 April 2018), on the Question of the Realization in All Countries of Economic, Social, and Cultural Rights, UN Doc. A/HRC/RES/37/13

HRC Res. 37/23 (6 April 2018), Promoting Mutually Beneficial Cooperation in the Field of Human Rights, UN Doc. A/HRC/RES/37/23

32/ Declaration on the Right to Peace, Human Rights Council, 24 June 2016, UN Doc. A/HRC/32/L.18

6th Report of Commission of Inquiry on Syria, Human Rights Council, 11 September 2013, UN Doc. A/HRC/24/46

Assault on medical care in Syria, Human Rights Council, 13 September 2013, UN Doc. A/HRC/24/CRP.2

From Rhetoric to Reality: A Global Call for Concrete Action Against Racism, Racial Discrimination, Xenophobia, and Related Intolerance, UN Human Rights Council,

9 October 2017, UN Doc. A/HRC/RES/36/24

Further promotion and encouragement of human rights and fundamental freedoms, including the question of the programme and methods of work of the Commission, UN Commission

on Human Rights, 21 February 1977, UN Doc. E/CN.4/RES/4(XXXIII) ..... 168

Progress report on the right of peoples to peace, Human Rights Council, 1 April 2011, UN Doc. A/HRC/17/39

Progress report on the right of peoples to peace, prepared by the drafting group of the Advisory Committee on the right of peoples to peace, 22 December 2010, UN Doc. A/HRC/AC/6/CRP.3

Promotion of the right to peace, 17 July 2012, UN Doc. A/HRC/RES/20/15

Report of the Human Rights Council Advisory Committee on the right of peoples to peace (Draft Declaration), 16 April 2012, Human Rights Council, Twentieth Session, agenda item 5, UN Doc. A/HRC/20/31 137, 139-42, 312, 164-5 
Report of the Office of the High Commissioner on the outcome of the expert workshop on the right of peoples to peace, Human Rights Council, 17 March 2010, UN Doc.

A/HRC/14/38 $137-8$

Report of the open-ended inter-governmental working group on the draft United Nations declaration on the right to peace, Human Rights Council, 26 April 2013, UN Doc. A/HRC/WG.13/1/2 137-8, 494

Report of the open-ended intergovernmental working group on a draft United Nations declaration on the right to peace, Human Rights Council, 8 August 2014, UN Doc. $\mathrm{A} / \mathrm{HRC} / 27 / 63$

Report of the open-ended intergovernmental working group on a draft United Nations declaration on the right to peace on its third session, Human Rights Council, 26 May 2015, UN Doc. A/HRC/29/45

Report of the Working Group on the issue of discrimination against women in law and in practice, Human Rights Council, Thirty-fifth session, 19 April 2017, UN Doc.

A/HRC/35/29, https://tinyurl.com/jlc3ulr (accessed 14 January 2018)

Report of the Working Group on the issue of discrimination against women in law and in practice on its mission to the United States of America, Human Rights Council, 4 August 2016, UN Doc. A/HRC/32/44/Add.2, available at: http://www.refworld.org/docid/5800dd4a4.html (accessed 14 January 2018) 340

Rights of Persons belonging to National or Ethnic, Religious, and Linguistic Minorities, UN Human Rights Council, 19 March 2018, UN Doc. A/HRC/37/L.25

\section{UN Secretary-General}

Advancement of Women Human Resources Management: Other Human Resources Questions Improvement of the Status of Women in the Secretariat, Report of the Secretary-General, 1 November 1994, UN Doc. A/49/587, paragraph 32. http://www.securitycouncilreport. org/atf/cf/\%7B65BFCF9B-6D27-4E9C-8CD3-CF6E4FF96FF9\%7D/WPS\%20A\%2049 \%20587.pdf (accessed 16 June 2014)

An Agenda for Peace: Preventive diplomacy, peacemaking and peace-keeping, Report of the Secretary-General pursuant to the statement adopted by the Summit Meeting of the Security Council on 31 January 1992, 17 June 1992, UN Doc. A/47/277-S/24111 $121-2,320-21,330,352,355,506$

A Vital and Enduring Commitment: Implementing the Responsibility to Protect, Report of the Secretary-General, 13 July 2015, UN Doc. A/69/981-S/2015/500 $133-4,437$

Early Warning, Assessment and the Responsibility to Protect, Report of the Secretary-General, 14 July 2010, UN Doc. A/64/864 437

Fulfilling Our Collective Responsibility: International Assistance and the Responsibility to Protect, Report of the Secretary-General, 11 July 2014, UN Doc.

$\mathrm{A} / 68 / 947-\mathrm{S} / 2014 / 449$

Guidance note of the Secretary-General: United Nations Assistance to Constitution-making Processes, April 2009 506

Implementing the Responsibility to Protect: Accountability for Prevention, Report of the

Secretary-General, 10 August 2017, UN Doc. A/71/1016-S/2017/556

Implementing the Responsibility to Protect, Report of the Secretary-General,

12 January 2009, UN Doc. A/63/677

In Larger Freedom: Towards Development, Security and Human Rights for all, Report of the Secretary-General, 21 March 2005, UN Doc. A/59/2005 94, 122, 131

Introduction to the Annual Report of the Secretary-General on the Work of the Organization, Report of the Secretary-General, 16 June 1960-15 June 1961, UN Doc. A/4800/Add.1, 1 \& 2

Mobilizing Collective Action: The Next Decade of the Responsibility to Protect, Report of the Secretary-General, 22 July 2016, UN Doc. A/70/999-S/2016/620 133,437 
Promotion and Protection of Human Rights, Fundamental Standards of Humanity, Report of the Secretary-General, 3 March 2006, UN Doc. E/CN./4/2006/87

Report by Secretary-General, United Nations Activities in Support of Mediation, 27 June 2017,

UN Doc. A/72/115, https://peacemaker.un.org/sites/peacemaker.un.org/files/

SGReport-Mediation-A-72-115\%282017\%29.Eng_.pdf (accessed 6 November 2017)

Report of the Secretary-General on the Work of the Organization, 2 September 1994,

UN Doc. A/49/1

Report of the Secretary-General on the Work of the Organization, September 2016,

UN Doc. A/71/1

Report of the Secretary-General on the Work of the Organization, September 2017,

UN Doc. A/72/1

Report of the United Nations Mission to Investigate Allegations of the Use of Chemical

Weapons in the Syrian Arab Republic on the alleged use of chemical weapons in the

Ghouta area of Damascus on 21 August 2013, Note by the Secretary-General,

16 September 2013, UN Doc. A/67/997-S/2013/553, http://www.un.org/disarmament/

content/slideshow/Secretary_General_Report_of_CW_Investigation.pdf (accessed

9 November 2014)

Responsibility to Protect: State Responsibility and Prevention, Report of the Secretary-General,

9 July 2013, UN Doc. A/67/929-S/2013/399 133,437

Responsibility to Protect: Timely and Decisive Response, Report of the Secretary-General,

25 July 2012, UN Doc. A/66/874-S/2012/578

Secretary-General's Bulletin: Observance by United Nations Forces of International

Humanitarian Law, Report of the Secretary-General, 6 August 1999, UN Doc.

ST/SGB/1999/13

Supplement to An Agenda for Peace: Position Paper of the Secretary-General on the Occasion of the Fiftieth Anniversary of the United Nations, Report of the Secretary-General,

25 January 1995, UN Doc. A/50/60-S/1995/1

The Relationship between Disarmament and Development, Report of the Secretary General,

1982, UN Doc. A/36/356

The Role of Regional and Sub-Regional Arrangements in Implementing the Responsibility to

Protect, Report of the Secretary General, 27 June 2011, UN Doc.

A/65/877-S/2011/393 ....

The Rule of Law and Transitional Justice in Conflict and Post-conflict Societies, Report of the

Secretary-General, 23 August 2004, UN Doc. S/2004/616

UN Secretary-General Address to the UN General Assembly, 19 September 2017, available at: https://www.un.org/sg/en/content/sg/speeches/2017-09-19/sgs-ga-address (accessed

21 June 2018)

Women's Participation in Peacebuilding, Report of the Secretary-General, 7 September 2010,

UN Doc. A/65/354-S/2010/446 $335-6,348$

Women and Peace and Security, Report of the Secretary-General, 29 September 2016, UN

Doc. $S / 2016 / 822$ $331-2,348-9$

\section{Committee Against Torture}

General Comment No. 3 'Implementation of Article 14 by States parties', UN Doc.

CAT/C/GC/3 (19 November 2012)

\section{Committee on Economic, Social and Cultural Rights}

CESCR, Concluding observations on the sixth periodic report of Colombia, UN Doc.

E/C.12/COL/CO/6 (19 October 2017)

General comment No. 20 'Non-Discrimination in Economic, Social and Cultural Rights', UN

Doc. E/C.12/GC/20 (2 July 2009) 286, 292, 297-8, 301, 330 
xlviii Research handbook on international law and peace

\section{Committee on Enforced Disappearances}

Concluding observations on the report submitted by Colombia under Article 29(1) of the Convention, UN Doc. CED/C/COL/CO/1 (27 October 2016)

\section{Committee on the Elimination of All Forms of Discrimination Against Women}

CEDAW Committee 'Concluding Observations on the combined seventh and eighth periodic reports of Colombia', UN Doc. CEDAW/C/COL/CO/7-8 (29 October 2013) ........ 330, 337

CEDAW Committee, 'Fatma Yildirim (deceased) v. Austria, Communication 6/2005', UN Doc. CEDAW/C/39/D/6/2005 (6 August 2007) .................................................................... 294

CEDAW Committee 'General recommendation on women's access to justice', UN Doc. CEDAW/C/GC/33 (23 July 2015) .............................................................. 306, 334-5

CEDAW Committee, 'Karen Tayag Vertido v. Philippines, Communication 18/2008', UN Doc. CEDAW/C/46/D/18/2008 (1 September 2010) 294, 305

CEDAW Committee 'Report on Mexico produced by the Committee on the Elimination of Discrimination against Women under Article 8 of the Optional Protocol to the Convention, and reply from the Government of Mexico', UN Doc.

CEDAW/C/2005/OP.8/MEXICO (January 10-28, 2005)

CEDAW Committee, 'Şahide Goekce (deceased) v. Austria, Communication 5/2005', UN Doc. CEDAW/C/39/D/5/2005 (6 August 2007)

General Recommendation No. 8 'Implementation of Article 8 of the Convention', 7th session (1988)

General Recommendation No. 18 'Disabled women', CEDAW Committee, UN Doc. A/46/38 at $3(1993)$

General Recommendation No. 19 'Violence against Women', CEDAW Committee, UN Doc. $\mathrm{A} / 47 / 38$ at 1 (1993)

General Recommendation No. 25 'On Article 4, paragraph 1, of the Convention on the Elimination of All Forms of Discrimination against Women, on temporary special measures', CEDAW Committee, UN Doc. HRI/GEN/1/Rev.7 at 282 (2004) ......... 292, 304

General Recommendation No. 26 'On women migrant workers', CEDAW Committee, UN Doc. CEDAW/C/2009/WP.1/R (2008) .................................................................. 302

General Recommendation No. 27 'On older women and protection of their human rights', CEDAW Committee, 2010, UN Doc. CEDAW/C/GC/27 (2010) ..................................... 302

General Recommendation No. 28 'On the Core Obligations of States Parties under Article 2 of the Convention on the Elimination of All Forms of Discrimination against Women', CEDAW Committee, UN Doc. CEDAW/C/GC/28 (2010) 294,301

General Recommendation No. 30 'Women in conflict prevention, conflict and post-conflict situations', UN Doc. CEDAW/C/GC/30 (18 October 2013) $330,335,337-8$, $343,345-6,348,350$

General Recommendation No. 33 'On women's access to justice', CEDAW Committee, UN Doc. CEDAW/C/GC/33 (2015) $306,334-5$

General Recommendation No. 35 'On gender-based violence against women, updating General Recommendation No. 19', CEDAW Committee, UN Doc. CEDAW/C/GC/35 (2017)

\section{Committee on the Elimination of Racial Discrimination}

Concluding observations on the combined fifteenth and sixteenth periodic reports of Colombia, International Convention on the Elimination of All Forms of Racial Discrimination, UN Doc. CERD/C/COL/CO/15-16 (25 September 2015)

TBB-Turkish Union in Berlin/Brandenburg v. Germany, Communication No. 48/2010 (adopted 4 April 2013)

The Jewish Community of Oslo et. al. v. Norway, Communication No. 30/2003, CERD/C/67/D/30/2003 (2005) 
General Recommendation No. 15 'Organized violence based on ethnic origin (Article 4)',

UN Doc. A/48/18 at 114 (23 March 1993)

General Recommendation No. 25 'Gender Related Dimensions of Racial Discrimination',

CERD Committee, UN Doc. A/55/18, Annex V at 152 (2000) ....

General Recommendation No. 27 'Discrimination against Roma', UN Doc. A/55/18,

Annex V at 154 (2000)

General Recommendation No. 30 'Discrimination against Non-citizens', UN Doc.

CERD/C/64/Misc.11/rev.3 (2004)

General Recommendation No. 32 'The meaning and scope of special measures in the

International Convention on the Elimination of All Forms Racial Discrimination',

CERD Committee, UN Doc. CERD/C/GC/32 (2009)

General Recommendation No. 34 'Racial discrimination against people of African descent',

UN Doc. CERD/C/GC/34 (2011) 297, 302, 304

\section{Committee on the Rights of Persons with Disabilities}

CRPD Committee 'Concluding observations on the initial report of Colombia', UN Doc. CRPD/C/COL/CO/1 (30 September 2016) ........................................................ 332, 338

\section{Organization for Security and Co-operation in Europe}

OSCE Permanent Council, 'Plenary meeting of the council', PC.DEL/644/14

OSCE, '1991 Valletta Report of the OSCE Meeting of Experts on Peaceful Settlement of

Disputes' (8 February 1991), http://www.osce.org/secretariat/30115?download=true

(accessed 7 November 2014)

OSCE, 'Gender Balance Report OSCE Parliamentary Assembly: The Effective Implementation of UN Security Council Resolution 1325 within the OSCE and in Participating States' (July 2013), Presented By Dr. Hedy Fry, Special Representative on Gender Issues of the OSCE PA, 23 http://www.oscepa.org/publications/reports/special-reports/ gender-issues-reports/1879-2013-sr-on-gender-issues-report/file (accessed 16 June 2014)

\section{Other UN Documents}

6th Report of Commission of Inquiry on Syria, Independent International Commission of Inquiry on the Syrian Arab Republic, 11 September 2013

Addendum to the Report of the United Nations High Commissioner for Refugees, UN High Commissioner for Refugees Executive Committee, 1982, UN Doc. A/37/12/Add.1 ...... 319

Agenda 21, United Nations Conference on Environment and Development (UNCED), Rio de Janeiro June 1992

Agenda for Protection, UN High Commissioner for Refugees Executive Committee, 2002, UN

Doc. A/AC.96/965/Add.1 325-6

A More Secure World: Our Shared Responsibility, Report of the Secretary-General's High-level

Panel on Threats, Challenges and Change (2004)

A New Global Partnership: Eradicate Poverty and Transform Economies through Sustainable

Development, The Report of the High Level Panel of Eminent Persons on the Post-2015

Development Agenda, New York UN Publications 2013

Children at Risk, UN High Commissioner for Refugees Executive Committee, 2007,

Conclusion No. 107 (LVIII)

Civil and Political Rights, Including the Question of Conscientious Objection to Military

Service, Report of the Office of the High Commissioner for Human Rights, 16 February

2004, UN Doc. E/CN.4/2004/55 $312-13$

Comprehensive and Regional Approaches Within a Protection Framework, UN High

Commissioner for Refugees Executive Committee, 1996, Conclusion No. 80

(XLVII) 
Conference Room Paper: Assault on Medical Care in Syria, United Nations Independent International Commission of Inquiry on the Syrian Arab Republic, 13 September 2013

Confidential Status Report II: Projects of Assistance to National Liberation Movements, UN High Commissioner for Refugees, 1974

Conscientious Objection to Military Service, United Nations, 1985, UN Doc. E/CN.4/Sub.2/1983/30/Rev.1

Convention Plus: Framework of Understandings on Resettlement, UN High Commissioner for Refugees, 2003, UN Doc FORUM/CG/RES/04

Decision 1/CP.16 The Cancun Agreements: Outcome of the Work of the Ad Hoc Working Group on Long-term Cooperative Action under the Convention, UN Framework Convention on

Climate Change, Conference of the Parties, FCCC/CP/2010/7/Add. 1

Decision 1/CP.21 Adoption of the Paris Agreement, UN Framework Convention on Climate

Change, Conference of the Parties, FCCC/CP/2015/10/Add.1

Decision 9/CP.19 Work Programme on results-based finance to progress the full implementation of the activities referred to in decision 1/CP.16, paragraph 70, UN Framework Convention on Climate Change, Conference of the Parties, FCCC/CP/2013/10/Add.1

Decision B.18/07 Readiness and Preparatory Support Programme: Progress Report, Green Climate Fund Board, 14 September 2017, GCF/B.18/07

Deprival of food, water, shelter and medical care - a method of war in Syria, and a crime against humanity, United Nations Office of the High Commissioner of Human Rights, 6 February 2014, http://www.ohchr.org/EN/NewsEvents/Pages/DisplayNews.aspx? NewsID $=14224 \&$

Documents of the United Nations Conference on International Organization San Francisco, London: United Nations Information Organizations, 1945

Expert Meeting on Complementarities between International Refugee Law, International Criminal Law and International Human Rights Law: Summary Conclusions, UN High Commissioner for Refugees, July 2011 310,312

Fragmentation of International Law: Difficulties Arising from the Diversification and Expansion of International Law, Report of the Study Group of the International Law Commission: Finalized by Martti Koskenniemi, UN Doc. A/CN.4/L.682, A/61/10, 400

Guidelines for the participation of partners (NGOs and individual experts) in the pre-sessional working group of the Committee on the Rights of the Child, 1999, UN Doc. CRC/C/90, Annex VIII 306

Guidelines on International Protection: Application of the Exclusion Clauses: Article $1 F$ of the 1951 Convention Relating to the Status of Refugees, UN High Commissioner for Refugees, Geneva 2003, UN Doc. HCR/GIP/03/05

Guidelines on International Protection No. 10: Claims to Refugee Status related to Military Service within the context of Article 1A (2) of the 1951 Convention and/or the 1967 Protocol relating to the Status of Refugees, UN High Commissioner for Refugees, 3 December 2013, UN Doc. HCR/GIP/13/10

Handbook on Procedures and Criteria for Determining Refugee Status under the 1951 Convention and the 1967 Protocol Relating to the Status of Refugees, UN High Commissioner for Refugees, Geneva 1992, UN Doc. HCR/IP/4/Eng/REV.1

Housing and property restitution in the context of the return of refugees and internally displaced persons, UN Sub-Commission on the Prevention of Discrimination and Protection of Minorities, 26 August 1998, Res 1998/26

Internally Displaced Persons: Human Rights Resolution 2005/46, Office of the High Commissioner for Human Rights, 19 April 2005, UN Doc. 
International Protection Considerations with regard to people fleeing the Syrian Arab Republic, Update IV, UN High Commissioner for Refugees, Geneva, November 2015

Investment Policy Framework for Sustainable Development, UN Conference on Trade and

Development, UNCTAD/DIAE/PCB/2015/5

Military attacks on refugee camps and settlements in Southern Africa and elsewhere, UN High Commissioner for Refugees Executive Committee, 1987, Conclusion No. 48

(XXXVIII)

Military Technical Agreement between the International Security Force (KFOR) and the governments of the Federal Republic of Yugoslavia and the Republic of Serbia (Kumanovo Agreement), 9 June 1999, 38 ILM 1217

Our Common Future, Report of the World Commission on Environment and Development

(UN 1987), http://www.un-documents.net/ocf-11.htm\#I (accessed

18 January 2018) 184, 219, 227-9

Pathways for Peace: Inclusive Approaches to Preventing Violent Conflict - Main Messages and Emerging Policy Directions, The United Nations and World Bank, World Bank, 2017; Pathways for Peace: Inclusive Approaches to Preventing Violent Conflict, The United Nations and World Bank, World Bank 2018 .............. 8, 163, 167, 175, 180, 182, 190, 217

Protection Guidelines Relating to Refugee Security, UN High Commissioner for Refugees, Geneva 1999

Protracted Refugee Situations, Executive Committee of the High Commissioner's Programme,

10 June 2004, UN Doc. EC/54/SC/CRP.14 308

Protracted Refugee Situations, UN High Commissioner for Refugees, 2008, PDES Background

Document, UN Doc. UNHCR/DPC/2008/Doc. 02 324

Religion-Based Refugee Claims under Article 1A(2) of the 1951 Convention and/or the 1967 Protocol Relating to the Status of Refugees, UN High Commissioner for Refugees, Geneva, 28 April 2004, UN Doc. HCR/GIP/04/06

Report by Ambassador Felix Schnyder on Military Attacks on Refugee Camps and Settlements in Southern Africa and Elsewhere, UN High Commissioner for Refugees Executive Committee, 1983, UN Doc. EC/SCP/26

Report by the Director-General on the Human Right to Peace, UNESCO, Doc. 29 C/59 (29 October 1997)

Report of the Conference of the Parties on its thirteenth session, held in Bali from 3 to 15 December 2007, Framework Convention on Climate Change, 14 March 2008, UN Doc. FCCC/CP/2007/6/Add.1, Decision 1/CP.13 Bali Action Plan

Report of the Panel on United Nations Peace Operations (Brahimi Report), Comprehensive review of the whole question of peacekeeping operations in all their aspects, General Assembly fifty-fifth session, 21 August 2000, UN Doc. A/55/305-S/2000/809 ......... 356-7, 380,506

Report of the Secretary-General on the United Nations Verification Mission in Colombia, United Nations Security Council, 27 December 2017, UN Doc. S/2017/1117 ...... 347, 349

Report of the Secretary-General to the Security Council on the United Nations Mission in Colombia, United Nations Security Council, 18 August 2016, UN Doc. S/2016/729, paragraph 31

Report of the United Nations Conference on the Human Environment (Stockholm Declaration), 5-16 June 1972, UN Doc. A/CONF.48/14/Rev.1 230,232

Rio Declaration on Environment and Development, Report of the United Nations Conference on Environment and Development, 12 August 1992, UN Doc. A/CONF.151/26 (Vol. I) $183,219,227,230,232$

Safe at Last? Law and Practice in Selected EU Member States with Respect to Asylum-Seekers Fleeing Indiscriminate Violence, UN High Commissioner for Refugees, 27 July 2011 
lii Research handbook on international law and peace

Statement by the President of the Security Council, Security Council, 30 April 1993, UN Doc. $\mathrm{S} / 25696$ $121-2$

Statute of the International Criminal Court, 17 July 1998, UN Doc. A/CONF.183/9

Art 2, 436

Art 5, 373

Art 8 bis, 441

Art 13(b), 390, 436

Art 16, 430, 436

Art 25, 446

Art 36(2), 438

Art 115(b), 436

Art 121(1), 436

Art 125,436

Summary Conclusions on International Protection of Persons Fleeing Armed Conflict and Other Situations of Violence, UN High Commissioner for Refugees, 20 December 2012

The General Framework Agreement for Peace in Bosnia and Herzegovina (Dayton Peace

Agreement), UN General Assembly, 14 December 1995, UN Doc. A/50/790

The Investment Policy Review Programme: A Framework for Attracting and Benefiting from

FDI, UN Conference on Trade and Development, UNCTAD/ITE/IPC/2008/3 (2008) ... 186

The Protection of National Security in IIAs, UN Conference on Trade and Development

(UNCTAD) Series on International Investment Policies for Development 2009

The Role of International Investment Agreements in Attracting Foreign Direct Investment to Developing Countries, UN Conference on Trade and Development (UNCTAD) 2009

The State of the World's Refugees - a Humanitarian Agenda, UN High Commissioner for Refugees, OUP 1997

United Nations General Assembly, 'Group of Governmental Experts on Developments in the Field of Information and Telecommunications in the Context of International Security', UN Doc. A/70/174, 22 July 2015

UNHCR Eligibility Guidelines for Assessing the International Protection Needs of Asylum-Seekers from Afghanistan, UN High Commissioner for Refugees, Geneva 2009

United Nations Peacekeeping Operations: Principles and Guidelines, UN: DPKO, 2008 $354,364,366$

World Investment Report 2012: Towards a New Generation of Investment Policies, UN

Conference on Trade and Development, UN 2012 185

\section{Council of Europe}

Resolution 90(6) of 10 May 1990 on a Partial Agreement Establishing the European Commission for Democracy through Law, adopted by the Committee of Minister

Turkey, Opinion no. 865/2016 of 12 December 2016 on Emergency Decree Laws Nos. 667-676 adopted following the failed coup of 15 July 2016, adopted by the Venice Commission

\section{EU Documents}

Climate Change and International Security, Paper from the High Representative and the European Commission to the European Council, 14 March 2007, S113/08, 4 


\section{African Commission on Human and People's Rights}

Democratic Republic of Congo/Burundi, Rwanda, Uganda, African Commission on Human and People's Rights, Communication 227/1999, Twentieth Activity Report, EX.CL/279(IX), Annex IV Communications $102-103$

\section{Inter-American Commission on Human Rights}

Fourth Report on the Situation of Human Rights in Guatemala, Inter-American Commission on Human Rights, 1 June 1993, OEA/Ser.L/V/II.83, Doc. 16 rev.

\section{International Commission on Intervention and State Sovereignty}

The Responsibility to Protect, Report of the International Commission on Intervention and

State Sovereignty, 1 January 2001 $128,130,142,437$

\section{Organisation for Economic Co-operation and Development}

States of Fragility: Understanding Violence, OECD 2016

Organization for Security and Co-operation in European Permanent Council

'Decision No. 1106 Initial Set of OSCE Confidence-Building Measures to Reduce the Risks of Conflict Stemming from the Use of Information and Communication Technologies', PC.DEC/1106, 3 December 2013

'Decision No. 1202 OSCE Confidence-Building Measures to Reduce the Risks of Conflict

Stemming from the Use of Information and Communication Technologies',

PC.DEC/1202, 10 March 2016 
Cecilia M. Bailliet - 9781788117470 